\title{
Implementation Process and Execution Factor of Arbitration Decision in Indonesia
}

\author{
Ismail Rumadan \\ Faculty of Law \\ University of National \\ Jakarta, Indonesia \\ ismailrdhan@gmail.com
}

\begin{abstract}
This study examines the process of implementation and the factor of execution of arbitration decision in Indonesia. Statutory and conceptual approaches to legislation have been applied in collecting data. Qualitative descriptive analysis is used in analyzing the content of the underlying law and related to the law of arbitration in Indonesia. Results show that barriers arising in the execution of the arbitration award in the settlement of accounts payable in Indonesia consist of juridical barriers and technical barriers, juridical obstacles comprising execution which can not necessarily be made, other possible remedies after arbitration, and dispute provisions can be solved through very limited arbitration.
\end{abstract}

Keywords - implementation; execution; arbitration decision

\section{INTRODUCTION}

The choice to resolve disputes through the judiciary is a matter of great concern to businesspeople because this litigation dispute can result in the importance of the parties, then overcome the slow, costly and not responsive to the needs of the parties [1].

According to M. Yahya Harahap, experience and observations have been proven, the settlement of disputes through courts is relatively slow due to [2]:

- Full of formality;

- Open appeal, cassation and reconsideration so that the process of completion, can be tortuous and takes a very long time. Can be years old even decades;

- Not to mention the emergence of various interventions or resistance from third parties (derden verzet), causing the completion of the more complicated and long.

Therefore, the parties to choose the settlement of disputes through non-litigation outside the court either through mediation forums, negotiations, conciliation or arbitration. The choice of an out-of-court dispute resolution forum is an effective forum for the realization of strengthened justice in the common interest.

The options for dispute resolution through arbitration with the ideal considerations mentioned above cannot be realized in practical terms, especially in the event of final settlement of the arbitral award through execution, if the losing party or other related parties or those with an interest in the object dispute through the resistance effort through the submission of the request for the cancellation of the arbitral award [3].

Constitution No. 30 of 1999 on Arbitration provides for the intervention of the Court in the settlement of disputes through arbitration, one of which is a request for the cancellation of an arbitral award submitted to the District Court. It is not uncommon for dissatisfied parties to the arbitral award to apply for the cancellation of the arbitral award [4].

The provision of article 70 of Law no. 30 Year 1999 states that against the arbitration ruling the parties may apply for the cancellation of such verdict missed the following elements:

- Letters or documents filed in the examination, after the judgment has been made, acknowledged as false or otherwise declared false;

- After the verdict is found, there is a decisive document, which is hidden by the opposing party; and

- The verdict is derived from the results of the tricks by one of the parties in the dispute.

In essence, to apply for the cancellation of an arbitral award shall be based on Article 70 of Law no. 30 of 1999. If it is related to the Elucidation of Article 70 of Law no. 30 of 1999, then the reasons for the arbitral award shall be declared by a court decision, in this case, a court decision. However, in its development, there is a lack of understanding in the practice of cancellation of the arbitral award through the District Court. Supreme Court Decision No. 396K/Pdt.Sus/2010 affirms a cancellation of an arbitral award can be made on the grounds of Article 70 of Law no. 30 of 1999. But on the other hand, the Supreme Court in its Decision. 03/Arb/.Btl / 2005 states 70 of Law no. 30 of 1999 [5].

Such conditions provide inconsistencies of the judiciary in the cancellation of the arbitral award. This it was also evident in the Supreme Court Decision No. 855 K/Pdt.Sus/2008 denying the request for the cancellation of the arbitral award for the criminal court ruling proving the reasons for the cancellation. However, the Decision of the District Court. 468/Pdt.G/2003/PN.Sby which has been corroborated by Supreme Court Decision No. $700 \mathrm{PK} / \mathrm{Pdt} / 2008$, which is essentially granted the petition for the cancellation of the 
arbitral award on the basis of Article 70 of Law no. 30 of 1999 without any decision.

Itswere undeniable that the uniformity of court decisions regarding the cancellation of the arbitral award can be counted on to ensure legal certainty for the parties to the dispute that it becomes the biggest factor for obstacles in the implementation of the arbitral award in Indonesia.

Based on the description, this study is aimed examining the process of implementing arbitration decisions and obstacles in the implementation of arbitration decisions in Indonesia.

\section{METHOD}

This study is a normative law study that examines the condition of the implementation process and the execution factor in the arbitration decision. To realize this goal, statutory and conceptual approaches to legislation have been applied in collecting data. Qualitative descriptive analysis is used in analyzing the content of the underlying law and related to the law of arbitration in Indonesia. Literature and related literature reviews are collected through library search for primary secondary data, while primary data is obtained from fieldwork by collecting laws that underlie arbitration legislation.

\section{RESULT AND DISCUSSION}

\section{A. Implementation Process (execution) Decision Arbitration}

The execution procedure of the Arbitration award is provided in Articles 59 through 64 of Law No. 30 of 1999 for National Arbitration, and Articles 65 to 69 for International Arbitration.

International Arbitration Decisions may be made in the following Indonesia if:

- International Arbitration Decision shall be imposed by Arbitrator or Arbitration Assembly in a country with which the Indonesian State is bound by treaty, bilaterally or multilaterally, on the acknowledgment and implementation of the International Arbitration Arrangement.

- The International Arbitration Decision as referred to in letter a, shall be limited to a decision which in accordance with the provisions of Indonesian law is included within the scope of commercial law.

- International Arbitration Decisions may be exercised in Indonesia limited to decisions not in conflict with public order.

- International Arbitration Decisions can be exercised in Indonesia after obtaining an execution from the Chairman of the Central Jakarta District Court, and

- The International Arbitration Decision as referred to in letter a concerning the Republic of Indonesia as one of the parties to the dispute can only be executed after obtaining an execution from the Supreme Court of the Republic of Indonesia which subsequently delegated to the Central Jakarta District Court.
Prior to execution, warning (aanmaning) is required, aanmaning is an action and effort made by the Chief Justice of a reprimand to a losing party in order to carry out the contents of the decision voluntarily. Aanmaning is done by calling the losing party by determining the day, date and time of the hearing in the summons. Provision of aanmaning by conducting an incidental session attended by the Chief Justice, the Registrar and the losing party, gives a warning or reprimand in order to carry out the arbitral award within eight days.

The execution shall be executed in accordance with the verdict of the verdict, if the executed goods are significantly different from the verdict, the Registrar or the Executioner shall terminate the execution, and make an official report that the execution cannot be executed because of the ruling with the object to be executed not in accordance with the reality in the field.

Event execution in it must load obvious things include:

- Type goods that are executed,

- Location, size and large goods still being executed,

- Present at least the parties executed,

- Affirmation and information supervision goods,

- Explanation of non-binding for which is not in accordance with the verdict

- Explanation could or at least execution run,

- Day, date, hour, month year implementation execution

and

Subsequently, a bailout of an execution event was signed by the executing execution official, two witnesses, the village chief and the executioner. Village Head / Sub-District Head, Sub-District Head and formal judicial executive are not required to sign the minutes. However, in order to avoid the things that may arise in the wake of the day, they should be required to sign the minutes of the execution made by the Clerk or the Bailiff carrying out the execution [6].

It is understood that the actual arbitral award has the legal standing and power equivalent to the judge's decision. However, on the other hand, the norm of arbitration law also adheres to double standards. Clearly, arbitral rulings, the status of existence, and legal powers are firmly positioned as decisions that are still heavily dependent on the authority of the District Court. A number of indications of such matters as in the arbitration law. Some of them are as follows:

- First, the national and international arbitration verdict to be executed requires the original or authentic copy of the decision to be submitted and registered by the arbitrator or his proxy to the court clerk of the District Court. Especially for the international arbitration award, it must be done in the Central Jakarta District Court.

- Second, national arbitration decisions that do not comply with the provisions of submission and 
enforcement of the judgment result in the ruling being unenforceable.

- Thirdly, the national arbitration award not voluntarily carried out by the parties, the decision is made under the orders of the Chairman of the District Court at the request of one of the parties.

- Fourth, specifically for the international arbitration award, the decision can be made in Indonesia after obtaining the execution from the Chairman of the Central Jakarta District Court.

The four indicators mentioned above, it can be said that the normative arbitration decision has actually been placed in a position not aligned with the judge's decision. That means the rules of arbitration law have established the norm ambivalence. Whether or not such norms have been realized has brought serious consequences to the legal status and the existence of the arbitral award.

Therefore, the efforts to be made and also should be positively arbitrated in the arbitration law in order for the arbitrage decision to have final and final binding legal force;

- The arbitration forum shall be affirmed of its independence and authority as one of the commercial examining institutions and dispute mediators or trade disputes outside the Court of Appeal. However, such efforts should not be done half-heartedly as has happened.

- Various elements that can reduce the position and authority of the arbitration forum should be abolished. Therefore, it is time for the arbitration forum's dependency on the competence of the District Court to be released at all, because it directly or indirectly has had an adverse impact on the existence of the arbitration forum itself.

- Arbitral award imposed wherever, nationally or internationally should not be registered and submitted or requested exequatur from the District Court. The problem, however, has clearly proven that the authority of the District Court to exercise a supervisory function on the dispute resolution mechanism outside the court, has impressed subordinate arbitral rulings under the competence of the District Court.

\section{B. Barriers to the Execution of Arbitral Verdicts}

The execution of the arbitral award does not always go smoothly in accordance with what is desired by the parties, the most important factor in the implementation of the arbitral award is the extent to which the executed parties accept sincerely the arbitration award that has been damaged, but if the arbitration award is not accepted voluntarily and sincerely then, the problem that then arises is, there is an effort to reveal the verdict through the judiciary. In such a position it becomes the main obstacle to the implementation of the arbitration award [6].

1) Obstacles to arbitration according to law number 30 year 1999: Although the basic concept of Law no. 30 Year
1999 final and binding, cannot be submitted an appeal, cassation or reconsideration [4]. However, as some things still have a chance for the parties to file a cancellation of the arbitral award. An arbitral award may be revoked in the event that the award of the arbitration is alleged to contain elements as defined in Article 70 of Law no. 30 [7]. The application for cancellation can only be made for the following reasons:

- The letter or document submitted in the examination, after the verdict has been imposed, is admitted falsely or otherwise declared false.

- After the verdict was taken, a kind of "novum" was found, which was found to be a decisive document, hidden by the other side.

- The award of arbitration shall be taken from the results of the deceit by one of the parties in the dispute.

However, the explanation of Article 70 is based on the decision of the Constitutional Court. 15/PUU/XII/2014, has been canceled for being ambiguous and containing new norms. The Court considers that Article 70 is sufficiently clear (expressis verbis), so it should not be interpreted otherwise. However, the interpretation of article 70 may be interpreted. For that reason, the provision can be interpreted whether the reason for filing the petition must be proven by the court in advance as a condition of filing the cancellation request or the reason for the cancellation is proven in the court hearing regarding the cancellation request.

The inconsistency is seen in Decision No. 396K/Pdt.Sus/2010 which confirms a cancellation of an arbitral award can only be made on the grounds of Article 70 of Law no. 30 of 1999. But on the other hand, the Supreme Court in its Decision. 03/Arb/.Bt1/2005 states that it is possible to cancel the arbitral award on the grounds outside Article 70 of Law no. 30 of 1999.

Even if it is possible to make cancellation of the arbitration decision, it is necessary to have a definite provision and uniform understanding especially regarding reasons for the cancellation of the arbitral award. Such a condition of uniformity may make the cancellation of this arbitral award as a gap for those who are dissatisfied with the decision to delay the exercise of the arbitral award. If this is the case, settling the case through arbitration will bring more expenses and will not be any sooner than direct trial [8].

2) Technical barriers to the execution of arbitral award: In addition to the barriers to the execution of the juridical arbitral award as described above, there are other technical barriers encountered in the execution of the arbitral award, among others, as follows:

a) The execution delegation: It is possible that the items being petitioned for execution are outside the jurisdiction of the Court that decides the case. The issue is how to carry out its execution, in this case, it can be pursued using the "execution delegation" institution as set forth in Article 206 R.Bg and Article 195 HIR. Namely the execution must be done through delegation or request for assistance to another 
court, to execute in accordance with the letter of determination submitted to him.

b) Resistance to execution: In the event of a third-party resistance ( derden verzet ) against the object of execution located outside the jurisdiction of the Court adjudicating the case to the Court where the third party's resistance is filed, whether to the Court adjudicating the case or to the Court conducting the execution, Pursuant to Article 206 paragraph (6) R.Bg. and Article 195 Paragraph (6) of the HIR, it is argued that the third party's resistance to the exercise of a verdict shall be exercised and tried by the Court conducting the judge's decision or to the Court where the execution is carried out. But according to Article 379 RV such third party resistance shall be filed in the Court which decides the case, not in the place of the Court which carries out its execution.

c) Execution cannot be executed: Among the obstacles that are often found in the field of execution-related property is absolute no executed goods are absent, may have been sold out before execution, or has been destroyed by natural disasters. Not seen treasures to be executed can also occur due to not clear where the goods are to be executed, it is not clear limits - limits, size and may also be due to a change of address, there is no matter relating to the completeness of letter mail, the cost, the appraised price (price) SKPT so that at the time of the auction process is still hampered let alone executed, if the location of the goods is no longer in accordance with what is in the verdict.

The goal only gives an opportunity to the executed party to prepare themselves to volunteer the object to be executed. So the execution delay ca not be permanent, only limited in a relatively short time. If the specified time limit has passed, execution must be executed without needing any more warning. There is also another reason that derdenverzet under section 195 of the third party HIR is granted the right to advocate for the execution exercised by the Court, the derdenverzet proposition is exercised on the basis of "property rights" that the executioner is the property of a party to the resistance. Execution is prohibited against third party property, postponement of new execution may be executed if the resistance raised by the third party has been examined in a thorough and thorough way. If the results of the examination prove to be true that the goods to be executed are the property of the opponent, then the execution must be postponed until the resistance gets a permanent lawful decision. The purpose of this delay is to avoid conflicting execution with the decision of resistance from a third party; in addition, if the object of execution is still processed in another case, the examination is still in the first level, appeal or cassation, it is better to delay the execution until the verdict obtained the strength of the law remains, the purpose of not making a conflicting decision [9].

\section{The role of a Very Dominant Judicial Institution}

The role of the court in the provision of arbitration under the Arbitration Act is, among other things, the appointment of the arbitrator or arbitral panel in the case of the parties there is no agreement (Article 14 (3) of the Arbitration Law) and in the case of the implementation of national and international arbitration rulings which must be made through the mechanism of the judicial system the verdict by submitting an authentic copy of the verdict.

In relation to the jurisdiction of the district court against the arbitration forum, Law No. 30 of 1999 is still very biased and contains a very ambivalent norm. The law still clearly gives more authority to the district court in interfering with the arbitration process. Strictly speaking in Article 3 of Law Number 30 Year 1999 it is stipulated that the court is not authorized to adjudicate the disputes of the parties that have been bound by the arbitration agreement, it is expected that the general court will expressly refuse and will not interfere in a dispute settlement which has been bound by clause arbitration.

\section{Dispute Provisions that can be Settled Through Arbitration are Strictly Limited}

Article 5 of the Arbitration Law, disputes that can be resolved through arbitration are merely disputes in the field of trade and on rights which, by law and legislation, are fully controlled by the parties to the dispute. In some cases in the Commercial Court, whether or not the arbitration clause arises in the case of a dispute arising in a bankruptcy lawsuit against one of the parties, the arbitration clause must be disregarded, there are two opinions for this matter. The first opinion says that the arbitration clause is something absolute. Accordingly, the Commercial Court must declare that it is not authorized to examine the dispute in which there is an arbitration clause in it.

\section{E. Limitations of Arbiter Capabilities}

However, the arbitration decision depends on the technical ability of the arbitrators to provide satisfactory and fair decisions for the parties. This technical capability should be tailored to the type of case handled by the arbitrator and the parties may designate their own arbitrator. However, the appointment of this arbitrator should be tailored to the type of case handled. Arbitrators themselves are professionals who are experts in a field. Surely they have their own reputation in the field.

\section{F. Difficulties in Arbitration Closing}

In preparing and formulating an arbitration clause, especially in terms of determining the scope of the dispute, it should be remembered that not all disputes may be submitted to arbitration. In Article $616 \mathrm{Rv}$ is governed what types of dispute may be submitted to the examination as well as its termination to arbitration. Many guidelines can be used in the preparation of the arbitration clause. If the arbitration we are referring to is an institutional arbitration, the preparation of the arbitration clause will have little difficulty. The standard clauses suggested by BANI in any treaty in which the parties wish to enter the arbitration clause are as follows: "All disputes arising from this agreement shall be settled and decided by the Indonesian National Arbitration Board (BANI) in accordance with administrative and regulatory-the arbitration procedure of BANI, whose decision is binding on both sides of the dispute, as a decision in the first and final level" [10]. 


\section{CONCLUSION}

The barriers arising in the execution of the arbitration award in the settlement of accounts payable in Indonesia consist of juridical barriers and technical barriers, juridical obstacles comprising execution which can not necessarily be made, other possible remedies after arbitration, and dispute provisions can be solved through very limited arbitration. The main obstacle in the execution of the arbitral award is Law no. 30 of 1999 provides an opportunity for resistance by one of the parties who does not accept the arbitration award voluntarily by applying for the cancellation of the arbitral award to the court, so that the execution of the arbitral award is ultimately hampered by the filing of the lawsuit, pending a permanent court verdict. In such a position the arbitration ruling that has a clear position, the status of existence, and legal force, is firmly positioned as a decision which is still very dependent on the authority of the District Court.

\section{ACKNOWLEDGEMENT}

The author would like to thank all the parties who have helped and contributed in the writing of this article, both those who contribute in the form of funding and critical ideas. Hopefully this paper can be useful theoretically and practically for the addition and development of knowledge, especially in the field of legal science.

\section{REFERENCES}

[1] http://www.library.usu.ac.id/download/fh/perda-dedi1.pdf (accessed on Januari 2, 2018).

[2] M. Y. Harahap, Beberapa Tinjauan Mengenai Sistem Peradilan dan Penyelesaian Sengketa, Citra AdityaBakti, Bandung, 1997.

[3] E. Rajagukguk, Arbitra sedalam putusan Pengadilan, Candra Pratama, Jakarta, 2000

[4] Rengganis, Tinjauan Yuridis Pembatalan Putusan Arbitrase Nasional Berdasarkan Pasal 70 Undang-Undang Nomor 30 Tahun 1999, Program Pascasarjana Fakultas Hukum, Universitas Indonesia, 2011.

[5] S. Yudowibowo, Eksekusi Putusan Arbitrase Internasional di Indonesia, (Sebuah Perspektif Atas Undang-Undang No. 30 Tahun 1999), Yustisia <Edisi Nomor 71 Mei- Agustus, 2007.

[6] Masduki, Faktor Penghambat Pelaksanaan Putusan Terhadap Perkara Perdata Nomor 19/Pdt.G/2003/Pn Ta Yang Telah Memiliki Kekuatan Hukum Tetap (Studi di Pengadilan Negeri Tulungagung), Jurnal Ilmu Hukum, MIZAN, Volume 1, Nomor 1, Juni, 2012.

[7] Undang-Undang Nomor. 30 Tahun 1999Tentang Arbitrasedan Alternatif Penyelesaian Sengketa.

[8] S. Gautama, ArbitraseDagangInternasional (Bandung: Alumni, 1979.

[9] B. Budiman, "Mencari Model Ideal penyelesaian Sengketa, Kajian Terhadap praktik Peradilan Perdata Dan undang-Undang Nomor 30 Tahun 1999”, 2018.

[10] Y. Y. Oscar. "Penting klasul arbitrase dalam perjanjian" http://notariatwatch.blogspot.com/2010/02/pentingnya-klausularbitrasedalam.htm. 2018. 